\title{
Analisis Dampak Permainan Problematika Sains terhadap Kecakapan Proses Sains Anak Umur 5-6 Tahun
}

\author{
Yossie Setyo Wardhani ${ }^{1}$, Sri Wahyuni ${ }^{2}$, Ach. Rasyad ${ }^{2}$ \\ ${ }^{1}$ Pendidikan Anak Usia Dini-Universitas Negeri Malang \\ ${ }^{2}$ Pendidikan Luar Sekolah-Universitas Negeri Malang
}

\begin{tabular}{l}
\hline INFO ARTIKEL \\
\hline Riwayat Artikel: \\
Diterima: 04-07-2019 \\
Disetujui: $17-07-2020$ \\
\hline
\end{tabular}

\section{Kata kunci:}

science problematic games; children aged 5-6 years; aspects of cognitive development; science process skills; permainan problematika sains; anak umur 5-6 tahun; aspek perkembangan kognitif; kecakapan proses sains

\author{
Alamat Korespondensi: \\ Yossie Setyo Wardhani \\ Pendidikan Anak Usia Dini \\ Universitas Negeri Malang \\ Jalan Semarang 5 Malang \\ E-mail: yossiesetyo55@gmail.com
}

\begin{abstract}
This research was conducted at Dharma Wanita Persatuan 1 TK Senggreng with the purpose of describing the influence of the game of science problems on children's science process skills and describing the differences in the influence from skills of science process for children aged 5-6 years on the treatment of science problematic games and conventional learning methods. This study used a quasy experiment research design that applied the pretest posttest control group a design with quantitative research methods. The results of this research indicate that the mean posttest data score of science process proficiency in the experimental class is 16.00 and is greater than the control class which is 6.10 or $16.00>6.10$. So, there are differences in the effect of science problematics games with conventional learning methods for science process skills in children aged 5 to 6 years.
\end{abstract}

ABSTRAK

\begin{abstract}
Abstrak: Penelitian ini dilaksanakan dengan tujuan mendeskripsikan dampak permainan problematika sains pada kecakapan proses sains anak serta mendeskripsikan perbedaan pengaruh kecakapan proses sains anak usia 5-6 tahun untuk perlakuan permainan problematika sains dan metode pembelajaran konvensional. Penelitian ini menggunakan rancangan penelitian quasy experiment dengan metode penelitian kuantitatif. Hasil dari riset ini mengindikasikan bahwa nilai rata-rata data postes kecakapan proses sains kelas eksperimen adalah 16,00 dan lebih besar daripada kelas kontrol yang bernilai 6,10 atau $16,00>6,10$. Jadi, terdapat perbedaan pengaruh permainan problematika sains dengan pembelajaran metode pembelajaran konvensional untuk kecakapan proses sains pada anak usia 5-6 tahun.
\end{abstract}

Anak yang telah menginjak masa Taman Kanak-Kanak usia 5-6 tahun diberkahi rasa keingintahuan yang besar (Gallenstein, 2005). Tugas pendidik Taman Kanak-kanak adalah memfasilitasi dan menstimulasi rasa ingin tahu anak dengan cara membimbing ke arah yang benar (Sudarmo \& Mariyati, 2018). Dalam pelaksanakan kegiatan pembelajaran anak di Taman Kanak-kanak diperlukan suatu kecakapan proses sains. Pengembangan untuk kecakapan proses sains bagi anak menurut Roza (2012) mempunyai kontribusi yang sangat pokok dalam menstimulasi aspek dari perkembangan kognitif pada dunia anak usia 5-6 tahun. Cara yang tepat harus dilakukan untuk membimbing anak dalam memenuhi rasa keingintahuan saat belajar sains dan dapat meningkatkan kecakapan dari proses sains anak yaitu dengan memberikan pengaturan permainan problematika sains yang ideal (Bose \& Seetso, 2016). Pengaturan permainan sains yang ideal menurut Hamari (Hamari , 2016) yaitu anak belajar bagaimana cara memecahkan masalah yang dihadapi melalui tahap pengamatan, mengklasifikasi, memberi kesimpulan, dan mengomunikasikan. Tahapan permainan problematika sains dalam belajar sains, harus dilakukan oleh anak secara sistematis (Petrovska, Sivevska, \& Cackov, 2013).

Penelitian tentang peningkatan perbedaan kemampuan kreativitas anak pada kemampuan sains dengan pendekatan konvensional dan konstektual telah dilakukan oleh Sumiyati (2010) yang menghasilkan adanya perbedaan hasil dari pengajaran yang diberikan. Penelitian lain juga dilakukan oleh Widayati (Widayati., 2013) dengan topik meningkatkan proses pembelajaran sains pada anak melalui implementasi metode percobaan di TK pada kelompok B yang menghasilkan kesimpulan bahwa metode eksperimen bisa meningkatkan kreativitas sains pada anak didik kelompok B. Pada penelitian yang lain, Sari, Nuryadin, \& Sujiono (2014) menghasilkan bahwa kemampuan sains untuk anak usia 5-6 tahun dapat ditingkatkan dengan melakukan pendekatan proyek. 
Kecakapan proses sains anak yang berusia 5-6 tahun yang berlokasi pada TK Dharma Wanita Persatuan 1 Senggreng Kecamatan Sumberpucung Kabupaten Malang masih rendah karena proses pembelajaran sains masih dilakukan melalui penugasan di majalah dengan metode pembelajaran konvensional. Hal ini mengakibatkan anak kurang bersemangat, tidak antusias mengikuti kegiatan pembelajaran, dan cenderung bermain sendiri daripada menyimak pembelajaran yang diberikan oleh guru. Masalah ini yang membuat peneliti untuk melaksanakan penelitian tentang pengaruh permainan problematika sains terhadap kecakapan proses sains anak usia 5-6 tahun di TK Dharma Wanita Persatuan 1 Senggreng Kecamatan Sumberpucung Kabupaten Malang. Dalam penelitian ini akan dipelajari tentang pengaruh permainan problematika sains pada kecakapan proses sains anak usia 5-6 tahun dan mengetahui apakah terdapat perbedaan pengaruh kecakapan proses sains pada anak usia 5-6 tahun pada perlakuan permainan problematika sains dan metode pembelajaran konvensional di TK Dharma Wanita Persatuan 1 Senggreng Kecamatan Sumberpucung Kabupaten Malang. Hipotesis kerja atau $\left(\mathrm{H}_{\mathrm{a}}\right)$ yang dikemukakan dalam riset ini yaitu permainan problematika sains berpengaruh pada kecakapan proses sains anak yang berusia 5-6 tahun (Susilowati, 2016) . Hipotesis nol $\left(\mathrm{H}_{\mathrm{o}}\right)$ hanya digunakan untuk menghitung uji hipotesis dengan Mann Whitney ( $U$ - Test) didasarkan pada hasil penghitungan dengan penggunaan aplikasi SPSS 19.0.(Mujianto, 2017).

\section{METODE}

Penelitian ini menggunakan rancangan penelitian quasy experiment yang mengaplikasikan pretest posttest control group a design dengan metode penelitian kuantitatif (Osman, 2012). Subjek yang dipergunakan pada riset ini yaitu anak didik yang berusia 5-6 tahun TK Dharma Wanita Persatuan 1 Senggreng Kecamatan Sumberpucung Kabupaten Malang tahun ajaran 2018/2019. Teknik sampel yang dipilih memanfaatkan teknik sampling purposive, yaitu dengan mengambil sampel berdasarkan perolehan kecakapan pada proses sains yang rendah (Dewi, 2012). Sampel yang dipergunakan terdiri atas dua kelas, yaitu kelompok B1 dan kelompok B2. Struktur rancangan penelitian dapat diketahui pada gambar 1, dimana dimulai dengan identifikasi masalah yang ada kemudian pembuatan serta penentuan subjek penelitian dimana akan diimplementasikan ke dua macam kelas yaitu kelas kontrol dan kelas eksperimen. Dari data yang didapat akan dianalisa sehingga menghasilkan kesimpulan tentang dampak penelitian yang dilakukan.

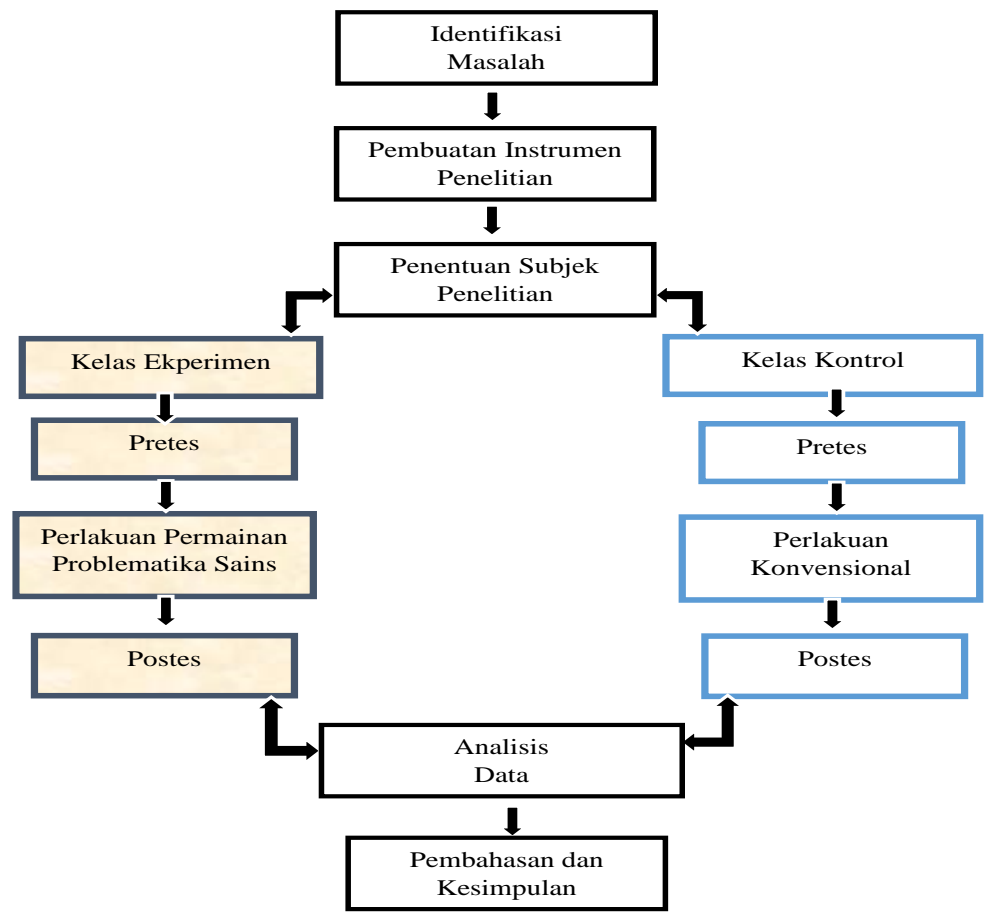

\section{Gambar 1. Metode Penelitian}

Instrumen yang diaplikasikan dalam riset ini yaitu berupa lembar untuk observasi, serta lembar penugasan. Lembar observasi yang dipergunakan pada penelitian ini dilaksanakan untuk mengawasi keterlaksanaan pembelajaran permainan problematika sains (Morrison, 2012). Lembar penugasan diaplikasikan oleh peneliti untuk mendapatkan hasil tes kecakapan proses sains yang dicapai anak terdiri atas lima soal. Teknik analisis data yang digunakan dalam riset ini adalah uji Shapiro Wilk untuk sampel yang jumlahnya kurang dari 30 dan Uji Mann Whitney ( $U$ - Test), untuk jumlah data sampel penelitian yang sangat sedikit dengan penggunaan aplikasi Microsoft Excel dan SPSS 19.0 (Oktaviani \& Notobroto, 2014) . 


\section{HASIL}

Pada bagian ini diuraikan data hasil dari riset yang telah diperoleh peneliti. Bersumber pada penelitian yang dilakukan di bulan November 2018 sampai bulan Januari 2019, terdapat dua kelas yang diberikan perlakuan berbeda-beda, yaitu kelompok B1 dijadikan kelas Eksperimen dan kelompok B2 dijadikan kelas kontrol. Berikut tabel desain eksperimen kelas eksperimen dan kelas kontrol (tabel 1).

Tabel 1. Desain Eksperimen Kelas Eksperimen dan Kelas Kontrol

\begin{tabular}{llll}
\hline Kelas & Pretes & Perlakuan & Postes \\
\hline Eksperimen & Y1 & X1 & Y2 \\
Kontrol & Y1 & - & Y2 \\
\hline
\end{tabular}

\footnotetext{
Keterangan:

Y1 : Pemberian tes lembar penugasan sebelum diberikan perlakuan permainan problematika sains

$\mathrm{X} 1$ : Perlakuan (permainan problematika sains)

$\mathrm{Y} 2$ : Pemberian tes lembar penugasan setelah diberikan perlakuan permainan problematika sains
}

Desain eksperimen untuk variabel bebas $(\mathrm{X})$ dan variabel terikat $(\mathrm{Y})$ dapat diketahui dari tabel 1 di atas yaitu Kelompok B1 selaku kelas eksperimen, melaksanakan permainan problematika sains, sedangkan kelompok B2 selaku kelas kontrol melaksanakan metode pembelajaran dengan cara konvensional. Pada penelitian ini, data yang dicantumkan berasal dari kecakapan proses sains yang dicapai anak melalui tes berupa lembar penugasan.

\section{Uji Instrumen Tes \\ Hasil Uji Validitas}

Uji validitas soal dilaksanakan untuk menguatkan bahwa instrumen yang dibuat sudah valid dan tepat

Tabel 2. Hasil Uji Validitas Pretes Lembar Penugasan Kecakapan Proses Sains Pada Anak Umur 5-6 Tahun Kelas Eksperimen

\begin{tabular}{|c|c|c|c|c|c|c|c|}
\hline \multicolumn{2}{|c|}{ Responden Kelas Eksperimen } & \multicolumn{5}{|c|}{ Nomor Soal } & \multirow[t]{2}{*}{$\begin{array}{c}\text { Jumlah } \\
(Y)\end{array}$} \\
\hline No & Nama & $1(X)$ & $2(X)$ & $3(X)$ & $4(X)$ & $5(X)$ & \\
\hline 1 & Arul & 4 & 4 & 3 & 4 & 4 & 19 \\
\hline 2 & Angel & 4 & 3 & 4 & 4 & 4 & 19 \\
\hline 3 & Attar & 3 & 2 & 2 & 4 & 4 & 15 \\
\hline 4 & Aska & 3 & 1 & 2 & 3 & 3 & 12 \\
\hline 5 & Bintang & 3 & 3 & 4 & 4 & 4 & 18 \\
\hline 6 & Finto & 4 & 3 & 3 & 3 & 2 & 15 \\
\hline 7 & Ilham & 2 & 2 & 3 & 3 & 4 & 14 \\
\hline 8 & Vina & 4 & 3 & 4 & 4 & 4 & 19 \\
\hline 9 & Ridho & 4 & 4 & 2 & 4 & 4 & 18 \\
\hline 10 & Sila & 4 & 4 & 4 & 4 & 4 & 20 \\
\hline 11 & Kaila & 4 & 3 & 4 & 4 & 4 & 19 \\
\hline 12 & Ricky & 4 & 4 & 3 & 3 & 4 & 18 \\
\hline Rxy & 0,693412 & 0,833509 & & 77892 & 0,709 & & 0,552099 \\
\hline t hitung & 3,043217 & 4,7706 & & 15938 & 3,181 & & 2,093947 \\
\hline $\mathrm{t}_{\text {tabel }}(95 \%, 10)$ & 1,812461 & & & & & & \\
\hline Keterangan & Valid & Valid & & & Valic & & Valid \\
\hline Jumlah Valid & 5 & & & & & & \\
\hline
\end{tabular}

Berdasarkan hitungan rumus korelasi Product Moment yang memanfaatkan program Microsoft Excel 2013, Lima soal yang diuji cobakan pada kelas eksperimen sebanyak 12 anak dinyatakan valid karena memiliki tingkat ketepatan $t_{\text {hitung }}>t_{\text {tabel }}$ pada setiap soal, yaitu (1) Soal butir nomor $1 t_{\text {hitung }}>t_{\text {tabel }}=3,043217>1,812461=$ valid, (2) Soal butir nomor $2 t_{\text {hitung }}>$ $t_{\text {tabel }}=4,7706>1,812461=$ valid, (3) Soal butir nomor $3 t_{\text {hitung }}>t_{\text {tabel }}=2,915938>1,812461=$ valid, (4) Soal butir nomor 4 $t_{\text {hitung }}>t_{\text {tabel }}=3,181248>1,812461=$ valid, (5) Soal butir nomor $5 t_{\text {hitung }}>t_{\text {tabel }}=2,093947>1,812461=$ valid. 
Tabel 3. Hasil Uji Validitas Pretes Lembar Penugasan Kecakapan Proses Sains Pada Anak Umur 5-6 Tahun Kelas Kontrol

\begin{tabular}{|c|c|c|c|c|c|c|c|}
\hline \multicolumn{3}{|c|}{ Responden Kelas Kontrol } & \multicolumn{4}{|c|}{ Nomor Soal } & \multirow{2}{*}{$\begin{array}{c}\text { Jumlah } \\
(\mathbf{Y})\end{array}$} \\
\hline No & Nama & $1(X)$ & $2(X)$ & $3(X)$ & $4(X)$ & $5(X)$ & \\
\hline 1 & Pyo & & 2 & 3 & 4 & 3 & 15 \\
\hline 2 & Intan & & 1 & 1 & 0 & 0 & 4 \\
\hline 3 & Andre & & 3 & 4 & 4 & 3 & 17 \\
\hline 4 & Lala & & 2 & 0 & 4 & 2 & 12 \\
\hline 5 & Pras & & 4 & 4 & 4 & 4 & 20 \\
\hline 6 & Aldi & & 4 & 4 & 4 & 3 & 18 \\
\hline 7 & Intansari & & 4 & 3 & 4 & 3 & 18 \\
\hline 8 & Vino & & 4 & 4 & 4 & 3 & 18 \\
\hline 9 & Zainal & & 1 & 4 & 4 & 3 & 16 \\
\hline 10 & Makaila & 0 & 3 & 1 & 4 & 3 & 15 \\
\hline \multicolumn{2}{|c|}{ Rxy } & 0,552151 & 0,747386 & 0,719225 & 0,87314 & 0,966452 & \\
\hline \multicolumn{2}{|c|}{ t hitung } & 1,873137 & 3,18176 & 2,927954 & 5,066195 & 10,64261 & \\
\hline \multicolumn{2}{|c|}{$\mathrm{t}_{\text {tabel }}(95 \%, 8)$} & 1,859548 & & & & & \\
\hline \multicolumn{2}{|c|}{ Keterangan } & Valid & Valid & Valid & Valid & Valid & \\
\hline \multicolumn{2}{|c|}{ Jumlah Valid } & 5 & & & & & \\
\hline
\end{tabular}

Tabel 4. Hasil Uji Reliabilitas Pretes Lembar Penugasan Kecakapan Proses Sains Pada Anak Umur 5-6 Tahun Kelas Eksperimen

\begin{tabular}{|c|c|c|c|c|c|c|c|}
\hline \multicolumn{3}{|c|}{ Responden Kelas Eksperimen } & \multicolumn{3}{|c|}{ Nomor Soal } & \multirow[b]{2}{*}{$5(X)$} & \multirow{2}{*}{ Jumlah $(\mathbf{Y})$} \\
\hline No & Nama & 1 & 2 & 3 & $4(X)$ & & \\
\hline 1 & Arul & 4 & 4 & 3 & 4 & 4 & 19 \\
\hline 2 & Angel & 4 & 3 & 4 & 4 & 4 & 19 \\
\hline 3 & Attar & 3 & 2 & 2 & 4 & 4 & 15 \\
\hline 4 & Aska & 3 & 1 & 2 & 3 & 3 & 12 \\
\hline 5 & Bintang & 3 & 3 & 4 & 4 & 4 & 18 \\
\hline 6 & Finto & 4 & 3 & 3 & 3 & 2 & 15 \\
\hline 7 & Ilham & 2 & 2 & 3 & 3 & 4 & 14 \\
\hline 8 & Vina & 4 & 3 & 4 & 4 & 4 & 19 \\
\hline 9 & Ridho & 4 & 4 & 2 & 4 & 4 & 18 \\
\hline 10 & Sila & 4 & 4 & 4 & 4 & 4 & 20 \\
\hline 11 & Kaila & 4 & 3 & 4 & 4 & 4 & 19 \\
\hline 12 & Ricky & 4 & 4 & 3 & 3 & 4 & 18 \\
\hline \multicolumn{2}{|c|}{ Varian butir soal } & 0,44697 & 0,839286 & 0,696429 & 0,242424 & 0,386364 & \\
\hline \multicolumn{2}{|c|}{ Jumlah Varian butir soal } & 2,611472 & & & & & \\
\hline \multicolumn{2}{|c|}{ Jumlah Varian total } & 6,333333 & & & & & \\
\hline \multicolumn{2}{|c|}{ Reliabilitas } & 0,734578 & & & & & \\
\hline
\end{tabular}

Pada tabel 3 di atas diperoleh data untuk hasil uji validitas pretes lembar penugasan kecakapan proses sains pada anak umur 5-6 tahun kelas kontrol. Dari tabel 3 tersebut berdasarkan hitungan rumus korelasi Product Moment yang memanfaatkan program Microsoft Excel 2013, lima soal yang diuji cobakan pada kelas kontrol sebanyak 10 anak dinyatakan valid karena memiliki tingkat ketepatan $t_{\text {hitung }}>t_{\text {tabel }}$ pada setiap soal, yaitu (1) Soal butir nomor $1 t_{\text {hitung }}>t_{\text {tabel }}=1,873137>1,859548$ $=$ valid, (2) Soal butir nomor $2 t_{\text {hitung }}>t_{\text {tabel }}=3,18176>1,859548=$ valid, (3) Soal butir nomor $3 t_{\text {hitung }}>t_{\text {tabel }}=2,927954>$ $1,859548=$ valid, (4) Soal butir nomor $4 t_{\text {hitung }}>t_{\text {tabel }}=5,066195>1,859548=$ valid, (5) Soal butir nomor $5 t_{\text {hitung }}>t_{\text {tabel }}$ $=10,64261>1,859548=$ valid.

\section{Hasil Uji Reliabilitas}

Uji reliabilitas soal dilaksanakan untuk mengetahui bahwa instrumen berupa tes lembar penugasan yang dibuat, menghasilkan skor yang relative stabil dan konsisten meskipun diujicobakan pada situasi yang berbeda. Berdasarkan data pada tabel 4, hitungan rumus Alpha yang memanfaatkan program Microsoft Excel 2013 bisa diketahui bahwa lima soal yang diuji cobakan pada kelas eksperimen sebanyak 12 anak dinyatakan reliabel karena $r_{\text {hitung }}>r_{\text {tabel }}$ dengan taraf signifikansi 5\%, yaitu $0,734578>0,05$. 
Tabel 5. Hasil Uji Reliabilitas Pretes Lembar Penugasan Kecakapan Proses Sains Pada Anak Umur 5-6 Tahun Kelas Kontrol

\begin{tabular}{|c|c|c|c|c|c|c|c|}
\hline \multicolumn{2}{|c|}{ Responden Kelas Kontrol } & \multicolumn{5}{|c|}{ Nomor Soal } & \multirow{2}{*}{ Jumlah } \\
\hline No & Nama & 1 & 2 & 3 & 4 & 5 & \\
\hline 1 & Pyo & 3 & 2 & 3 & 4 & 3 & 15 \\
\hline 2 & Intan & 2 & 1 & 1 & 0 & 0 & 4 \\
\hline 3 & Andre & 3 & 3 & 4 & 4 & 3 & 17 \\
\hline 4 & Lala & 4 & 2 & 0 & 4 & 2 & 12 \\
\hline 5 & Pras & 4 & 4 & 4 & 4 & 4 & 20 \\
\hline 6 & Aldi & 3 & 4 & 4 & 4 & 3 & 18 \\
\hline 7 & Intansari & 4 & 4 & 3 & 4 & 3 & 18 \\
\hline 8 & Vino & 3 & 4 & 4 & 4 & 3 & 18 \\
\hline 9 & Zainal & 4 & 1 & 4 & 4 & 3 & 16 \\
\hline 10 & Makaila & 4 & 3 & 1 & 4 & 3 & 15 \\
\hline \multicolumn{2}{|c|}{ Varian butir soal } & 0,48889 & 1,51111 & 2,4 & 1,6 & 1,122222 & \\
\hline \multicolumn{2}{|c|}{ Jumlah Varian butir soal } & 7,12222 & & & & & \\
\hline \multicolumn{2}{|c|}{ Jumlah Varian total } & 20,6778 & & & & & \\
\hline \multicolumn{2}{|c|}{ Reliabilitas } & 0,819452 & & & & & \\
\hline
\end{tabular}

Dari tabel 5 di atas diperoleh perhitungan berdasarkan rumus Alpha yang memanfaatkan program Microsoft Excel 2013 , lima soal yang diuji cobakan pada kelas kontrol sebanyak 10 anak dinyatakan reliabel karena $r_{\text {hitung }}>r_{\text {tabel }}$ dengan taraf signifikansi $5 \%$, yaitu $0,819452>0,05$.

\section{Uji Hasil}

\section{Hasil Uji Normalitas}

Uji normalitas dilaksanakan agar dapat mengetahui kenormalan dari distribusi data yang dipergunakan dalam uji hipotesis. Dalam pengambilan keputusan, apabila nilai signifikansi > 0,05 maka data memiliki distribusi normal, dan apabila nilai signifikansi < 0,05 maka data tidak berdistribusi normal (Risda Amini \& A. munandar, 2010). Data yang digunakan pada uji normalitas yaitu data pretes, postes 1, dan postes 2 lembar penugasan kecakapan proses sains anak kelompok B1 sebagai kelas eksperimen, dan anak kelompok B2 sebagai kelas kontrol. Hasil uji normalitas menggunakan analisis Shapiro Wilk dengan SPSS 19.0 dapat dilihat pada tabel 6, 7, dan 8 berikut.

Tabel 6. Hasil Uji Normalitas Data Pretes Lembar Penugasan Kecakapan Proses Sains

\begin{tabular}{llll}
\hline \multirow{2}{*}{ Tests Of Normality } & \multicolumn{3}{c}{ Shapiro-Wilk } \\
\cline { 2 - 4 } & Statistic & Df & Sig. \\
\hline Kelas Eksperimen & .886 & 10 & .153 \\
Kelas Kontrol & .800 & 10 & .015 \\
\hline
\end{tabular}

Berdasarkan data tabel 6 di atas, hasil uji normalitas data pretes lembar penugasan kecakapan untuk proses sains pada kelas eksperimen memiliki distribusi yang normal, dikarenakan memiliki nilai signifikansi sebesar 0,153. Hasil uji normalitas data pretes lembar penugasan kecakapan untuk proses sains kelas kontrol tidak mempunyai distribusi yang normal, karena mempunyai nilai signifikansi sebesar 0,015 .

Tabel 7. Hasil Uji Normalitas Data Postes 1 Lembar Penugasan Kecakapan Proses Sains

\begin{tabular}{lccc}
\hline \multirow{2}{*}{ Tests of Normality } & \multicolumn{3}{c}{ Shapiro-Wilk } \\
\cline { 2 - 4 } & Statistic & Df & Sig. \\
\hline Kelas Eksperimen & .924 & 10 & .389 \\
Kelas Kontrol & .953 & 10 & .703 \\
\hline
\end{tabular}

Berdasarkan data pada tabel 7 diatas, hasil uji normalitas postes 1 lembar penugasan kecakapan untuk proses sains kelas eksperimen serta kontrol mempunyai nilai signifikansi sebesar 0,389 dan 0,703. Jadi, data postes 1 lembar penugasan kecakapan proses sains kelas eksperimen serta kelas kontrol memiliki distribusi yang normal. 
Tabel 8. Hasil Uji Normalitas Data Postes II Lembar Penugasan Kecakapan Proses Sains

\begin{tabular}{lccc}
\hline \multirow{2}{*}{ Tests of Normality } & \multicolumn{3}{c}{ Shapiro-Wilk } \\
\cline { 2 - 4 } & Statistic & Df & Sig. \\
\hline Kelas Eksperimen & .859 & 10 & .074 \\
Kelas Kontrol & .882 & 10 & .137 \\
\hline
\end{tabular}

Berdasarkan tabel 8 diatas, hasil uji normalitas postes 2 lembar penugasan kecakapan proses sains kelas eksperimen dan kontrol mempunyai nilai signifikansi sebesar 0,074 dan 0,137. Jadi, data postes dua lembar penugasan kecakapan proses sains kelas eksperimen serta kelas kontrol memiliki distribusi yang normal.

\section{Hasil Uji Hipotesis}

Analisis Mann Whitney (U-Test) dipergunakan untuk uji hipotesis dengan bantuan program SPSS 19.0 untuk menentukan keputusan tentang apakah hipotesis nol diterima atau ditolak. Data yang dipergunakan dalam uji hipotesis adalah data postes 1 dan data postes 2 lembar penugasan kecakapan proses sains anak kelompok B1 sebagai kelas eksperimen, dan anak kelompok B2 sebagai kelas kontrol. Pengambilan keputusan pengujian menggunakan tingkat signifikansi 0,05. Jika nilai $\mathrm{Sig}>0.05$, maka $\mathrm{H}_{0}$ diterima, dan jika nilai Sig < 0.05 , maka $\mathrm{H}_{\mathrm{o}}$ ditolak. Rumusan hipotesis dalam riset ini adalah sebagai berikut.

$\mathrm{H}_{\mathrm{o}}$ : Kedua populasi identik. Data nilai kecakapan proses sains anak melalui permainan problematika sains dan melalui metode pembelajaran konvensional tidak berbeda secara signifikan.

$\mathrm{H}_{\mathrm{a}}$ : Kedua populasi tidak identik atau berbeda dalam hal nilai kecakapan proses sains. Data nilai kecakapan proses sains anak melalui permainan problematika sains dan melalui metode pembelajaran konvensional berbeda secara signifikan. Hasil dari uji hipotesis menggunakan analisis Mann Whitney ( $U$ - Test) dengan penggunaan aplikasi SPSS 19.0 dapat dilihat pada tabel 9 berikut.

Tabel 9. Hasil Uji U-Test Pemeringkatan Seluruh Nilai Kelas Eksperimen dan Kelas Kontrol Postes 1 Lembar

Penugasan Kecakapan Proses Sains

\begin{tabular}{llccc}
\hline \multicolumn{5}{c}{ Rank } \\
\hline & \multicolumn{1}{c}{ Kelas } & N & Mean Rank & Sum of Rank \\
\hline Kecakapan Proses & Kelas Eksperimen & 12 & 15.79 & 189.50 \\
Sains & Kelas Kontrol & 10 & 6.35 & 63.50 \\
\cline { 2 - 5 } & Total & 22 & & \\
\hline
\end{tabular}

Rata-rata (mean) data postes 1 lembar penugasan kecakapan untuk proses sains kelas eksperimen 15,79 lebih besar daripada kelas kontrol 6,35 atau 15,79 > 6,35. Jadi, terdapat perbedaan pengaruh permainan problematika sains dengan pembelajaran metode pembelajaran konvensional terhadap kecakapan untuk proses sains anak umur 5-6 tahun.

Tabel 10. Hasil Uji U-Test Nilai Statistik Kelas Eksperimen dan Kelas Kontrol Postes 1 Lembar Penugasan Kecakapan

\section{Proses Sains}

\begin{tabular}{lc}
\hline Test Statistics $^{\mathbf{b}}$ & Kecakapan Proses Sains \\
\hline Mann-Whitney U & 8.500 \\
Wilcoxon W & 63.500 \\
Z & -3.456 \\
Asymp. Sig. (2-tailed) & .001 \\
Exact Sig. [2*(1-tailed Sig.)] & $.000^{\mathrm{a}}$ \\
\hline
\end{tabular}

Tabel 10 di atas didapat dari penghitungan hasil uji U-Test untuk kelas eksperimen dan kelas control. Berdasarkan hasil analisis uji $U$-Test data postes 1 kecakapan proses sains Asymp. Sig nilai (2-tailed) adalah 0,001. Jadi, nilai signifikan 0,001 < 0,05 , maka $\mathrm{H}_{\mathrm{o}}$ ditolak dan $\mathrm{H}_{\mathrm{a}}$ diterima.

Tabel 11. Hasil Uji U-Test Pemeringkatan Seluruh Nilai Kelas Eksperimen dan Kelas Kontrol Postes Dua Lembar Penugasan Kecakapan Proses Sains

\begin{tabular}{llccc}
\hline \multicolumn{4}{c}{ Rank } & \\
\hline \multicolumn{1}{c}{ Kelas } & N & Mean Rank & Sum of Rank \\
\hline Kecakapan Proses & Kelas Eksperimen & 12 & 16.00 & 192.00 \\
Sains & Kelas Kontrol & 10 & 6.10 & 61.00 \\
\cline { 2 - 5 } & Total & 22 & & \\
\hline
\end{tabular}


Dari tabel 11 yang didapat dari hasil uji tes pemeringkatan seluruh nilai kelas didapat rata-rata (mean) data postes dua kecakapan proses sains kelas eksperimen 16,00 lebih besar daripada kelas kontrol 6,10 atau 16,00 > 6,10. Jadi, terdapat perbedaan pengaruh permainan problematika sains dengan pembelajaran metode pembelajaran konvensional terhadap kecakapan proses sains anak umur 5-6 tahun.

Tabel 12. Hasil Uji U-Test Nilai Statistik Kelas Eksperimen dan Kelas Kontrol Postes Dua Lembar Penugasan

\begin{tabular}{lc}
\multicolumn{2}{c}{ Kecakapan Proses Sains } \\
\hline Test Statistics & Kecakapan Proses Sains \\
\hline Mann-Whitney U & 6.000 \\
Wilcoxon W & 61.000 \\
Z & -3.616 \\
Asymp. Sig. (2-tailed) & .000 \\
Exact Sig. [2*(1-tailed Sig.)] & $.000^{\mathrm{a}}$ \\
\hline
\end{tabular}

Berdasarkan hasil analisis uji $U$-Test data postes 2 kecakapan proses sains dari tabel 12 di atas didapat Asymp. Sig nilai (2-tailed) adalah 0,000. Jadi, nilai signifikan $0,000<0,05$, maka $\mathrm{H}_{\mathrm{o}}$ ditolak dan $\mathrm{H}_{\mathrm{a}}$ diterima.

\section{PEMBAHASAN}

Permainan problematika sains merupakan permainan yang sangat berdampak kepada kecakapan proses sains pada anak usia 5-6 tahun. Kegiatan bermain pada aktivitas permainan problematika sains sangat tepat untuk menstimulasi kecakapan proses sains pada anak usia 5-6 tahun dikarenakan memanfaatkan bahan ajar sains yang sesuai karakteristik perkembangan kognitif pada anak usia 5-6 tahun. Gagasan dan pengetahuan anak dapat terbangun bukan hanya bergantung terhadap karakteristik objek, namun anak memahami suatu objek dengan memproses informasi yang diterima sehingga dapat diperoleh dan dibangun suatu gagasan baru untuk menyelesaikan masalah yang terkait dengan kejadian lingkungan sekitar anak.

Pengukuran pencapaian kecakapan proses sains menggunakan analisis Mann Whitney (U-Test) (Sriwidadi, 2011) dengan penggunaan program SPSS 19.0. Pengaruh permainan problematika sains terhadap kecakapan proses sains, ditunjukkan dari hasil analisis uji $U$-Test nilai statistik kelas eksperimen dan kelas kontrol, yaitu (1) data postes I lembar penugasan kecakapan proses sains Asymp. Sig nilai (2-tailed) adalah 0,001, jadi nilai signifikan 0,001 < 0,05, maka $\mathrm{H}_{\mathrm{o}}$ ditolak dan $\mathrm{H}_{\mathrm{a}}$ diterima, (2) Hasil analisis uji $U$-Test nilai statistik kelas eksperimen serta kelas kontrol data postes II lembar penugasan kecakapan proses sains Asymp. Sig nilai (2-tailed) adalah 0,000, jadi nilai signifikan 0,000 $<0,05$, maka $\mathrm{H}_{\mathrm{o}}$ ditolak dan $\mathrm{H}_{\mathrm{a}}$ diterima.

Sesuai dengan hasil analisis uji $U$-Test data postes I dan data postes II lembar penugasan kecakapan proses sains yang telah dipaparkan, pengambilan keputusan hipotesis penelitian yaitu, $\mathrm{H}_{\mathrm{o}}$ ditolak dan $\mathrm{H}_{\mathrm{a}}$ diterima. Jadi, permainan problematika sains berdampak kepada kecakapan proses sains anak usia 5-6 tahun. Hasil penelitian permainan problematika sains dengan penelitian quasy experiment semufakat dengan hasil riset yang dilaksanakan oleh Agustini, dkk (Setia, Agustini, Gading, \& Tirtayani, 2016) bahwa pengaruh yang signifikan terhadap kecakapan proses sains pada anak dipengaruhi oleh kegiatan dengan metode pembelajaran eksperimen.

Perbedaan pengaruh permainan problematika sains dengan pembelajaran metode pembelajaran konvensional terhadap kecakapan proses sains anak untuk umur 5-6 tahun, di TK Dharma Wanita Persatuan 1 Senggreng Kecamatan Sumberpucung Kabupaten malang didapatkan dari 2 data, yaitu pelaksanaan postes i dan postes ii tes lembar penugasan kecakapan proses sains pada anak usia 5-6 tahun kelompok B. Pelaksanaan postes I dilaksanakan pada hari Kamis, 3 Januari 2019. Kelompok B1 sebagai kelas eksperimen serta kelompok B2 sebagai kelas kontrol dijadikan satu kelas mengerjakan lembar penugasan sebanyak lima butir soal. Berikut hasil postes I lembar penugasan kecakapan proses sains pada anak usia $5-6$ tahun.

\section{Kelas Eksperimen}

Berdasarkan hitungan rumus dengan bantuan Microsoft Excel 2013, dari 12 anak kelas B1 yang mengikuti postes I lembar penugasan, yaitu (1) satu anak mendapatkan skor tertinggi dengan jumlah skor total 20, (2) enam anak mendapatkan jumlah skor total 19, (3) dua anak mendapatkan jumlah skor total 18, (4) dua anak mendapatkan jumlah skor total 17, (5) satu anak mendapatkan skor terendah dengan jumlah skor total 16.

\section{Kelas Kontrol}

Berdasarkan hitungan rumus dengan bantuan Microsoft Excel 2013, dari 12 anak kelas B1 yang mengikuti postes I lembar penugasan, yaitu (1) satu anak mendapatkan skor tertinggi dengan jumlah skor total 20, (2) enam anak mendapatkan jumlah skor total 19, (3) dua anak mendapatkan jumlah skor total 18, (4) dua anak mendapatkan jumlah skor total 17, (5) satu anak mendapatkan skor terendah dengan jumlah skor total 16. 
Pelaksanaan postes II tes lembar penugasan kecakapan proses sains pada anak usia 5-6 tahun kelompok di TK Dharma Wanita Persatuan 1 Senggreng Kecamatan Sumberpucung Kabupaten Malang dilaksanakan pada hari Sabtu, 19 Januari 2019. Kelompok B1 sebagai kelas eksperimen serta kelompok B2 sebagai kelas kontrol dijadikan satu kelas mengerjakan lembar penugasan sebanyak lima butir soal. Berikut hasil postes II penugasan kecakapan proses sains pada anak usia 5-6 tahun.

\section{Kelas Eksperimen}

Berdasarkan hitungan rumus dengan bantuan Microsoft Excel 2013, dari 12 anak kelas B1 yang mengikuti postes II lembar penugasan, yaitu (1) empat anak mendapatkan skor tertinggi dengan jumlah skor total 20, (2) tiga anak mendapatkan jumlah skor total 19, (3) 4 anak mendapatkan jumlah skor total 18, (4) satu anak mendapatkan skor terendah dengan jumlah skor total 17.

\section{Kelas Kontrol}

Berdasarkan hitungan rumus dengan bantuan Microsoft Excel 2013, dari 10 anak kelas B2 yang mengikuti postes II lembar penugasan, yaitu (1) dua anak mendapatkan skor tertinggi dengan jumlah skor total 18, (2) satu anak mendapatkan jumlah skor total 15, (3) tiga anak mendapatkan jumlah skor total 14, (4) tiga anak mendapatkan jumlah skor total 10, (5) satu anak mendapatkan skor terendah dengan jumlah skor total 5.

Perbedaan pengaruh permainan problematika sains dengan metode pembelajaran konvensional, ditunjukkan dari pengukuran pencapaian kecakapan proses sains menggunakan analisis Mann Whitney (U-Test) dengan bantuan aplikasi SPSS 19.0 for Windows, dari hasil uji U-Test pemeringkatan seluruh nilai kelas eksperimen dan kelas kontrol.

Data dari postes I lembar penugasan kecakapan proses sains menunjukkan rata-rata (mean), bahwa kecakapan proses sains kelas eksperimen 15,79 lebih besar daripada kelas kontrol 6,35 atau 15,79> 6,35. Hasil rendah yang didapatkan kelas kontrol melalui metode pembelajaran konvensional sesuai dengan pernyataan Agustini, dkk (Setia et al., 2016) bahwa pembelajaran yang dilakukan di TK bersifat mendemonstrasikan dan cenderung menggunakan majalah, mengakibatkan kecakapan proses sains anak belum berkembang dengan maksimal.

Data postes II lembar penugasan kecakapan proses sains menunjukkan rata-rata (mean), bahwa kecakapan proses sains kelas eksperimen 16,00 lebih besar daripada kelas kontrol 6,10 atau 16,00 > 6,10. Hasil tinggi yang didapatkan kelas eksperimen melalui permainan problematika sains sama dengan pendapat Moursund (Moursund, 2006) bahwa Permainan dapat menciptakan lingkungan dimana anak-anak dapat meningkatkan tingkat kematangan aspek kognitif mereka. Permainan memberikan pengalaman belajar memecahkan masalah pada anak untuk mengalami, dan menghadapi situasi kehidupan sehari-hari. Kognitif dalam diri anak akan berupaya untuk memecahkan masalah dengan menganalisa persoalan yang terdapat dalam setiap permainan

Berdasrkan hasil uji $U$-Test pemeringkatan seluruh nilai kelas eksperimen dan kelas kontrol data postes I dan data postes II dapat diambil keputusan, yaitu terdapat perbedaan pengaruh permainan problematika sains dengan pembelajaran metode pembelajaran konvensional terhadap kecakapan proses sains anak usia 5-6 tahun. Hasil keputusan semufakat dengan hasil penelitian yang dilakukan oleh Sari, dkk (Sari et al., 2014) yang menyatakan bahwa proses kegiatan pembelajaran sains anak yang mengarah pada kegiatan calistung menyebabkan kecakapan proses sains anak tidak dapat berkembang secara optimal.

Bersumber pada teori aspek perkembangan kognitif Jean Piaget (Ibda, 2015), anak usia 5-6 tahun berada pada tahap pra operasional. Tahap pra operasional menurut Jean Piaget dalam Ibda, F (2015) merupakan usia anak terletak pada rentang usia 5-6 tahun yang memiliki ciri mental experiment, dimana anak ingin mendapatkan jawaban dari permasalahan yang dihadapi harus melaksanakan suatu percobaan yang menyelidik. Aktivitas permainan problematika sains uji gigi dan permainan problematika sains tenggelam atau berenang, yaitu kegiatan penyelidikan berupa percobaan sederhana terkait kejadian lingkungan sekitar anak. Menghasilkan pengaruh yang signifikan terhadap keterampilan proses sains pada anak kelompok eksperimen yang berusia 5-6 tahun di TK Dharma Wanita Persatuan 1 Senggreng Kecamatan Sumberpucung Kabupaten Malang.

\section{SIMPULAN}

Berdasarkan hasil penelitian yang maka didapatkan kesimpulan, sebagai berikut. Pertama, permainan problematika sains berpengaruh pada kecakapan proses sains anak usia 5-6 tahun. Pengaruh terhadap kecakapan proses sains ditunjukkan setelah melakukan permainan problematika sains yang diukur menggunakan tes berupa lembar penugasan, yaitu kemampuan yang dicapai oleh anak. Pengukuran pencapaian kecakapan proses sains menggunakan analisis Mann Whitney (U- Test). Pengaruh permainan problematika sains pada kecakapan proses sains, ditunjukkan dari hasil analisis uji $U$-Test nilai statistik kelas eksperimen serta kelas kontrol yaitu, (1) data postes I lembar penugasan kecakapan proses sains Asymp. Sig nilai (2-tailed) adalah 0,001, jadi nilai signifikan $0,001<0,05$, maka $\mathrm{H}_{\mathrm{o}}$ ditolak dan $\mathrm{H}_{\mathrm{a}}$ diterima, (2) hasil analisis uji U-Test nilai statistik kelas eksperimen dan kelas kontrol data postes II lembar penugasan kecakapan proses sains Asymp. Sig nilai (2-tailed) adalah 0,000, jadi nilai signifikan $0,000<0,05$, maka $\mathrm{H}_{\mathrm{o}}$ ditolak dan $\mathrm{H}_{\mathrm{a}}$ diterima. Sesuai dengan hasil analisis uji $U$-Test data postes $\mathrm{I}$ dan data postes II lembar penugasan kecakapan proses sains yang telah dipaparkan, pengambilan keputusan hipotesis penelitian yaitu, $\mathrm{H}_{\circ}$ ditolak dan $\mathrm{H}_{\mathrm{a}}$ diterima. Jadi, permainan problematika sains berdampak kepada kecakapan proses sains anak usia 5-6 tahun. 
Kedua, ada perbedaan pengaruh permainan problematika sains dengan pembelajaran metode pembelajaran konvensional kepada kecakapan proses sains pada anak usia 5-6 tahun. Pengukuran perbedaan pengaruh terhadap kecakapan proses sains menggunakan analisis Mann Whitney (U-Test) yang ditunjukkan dari rata-rata (mean) hasil uji U-Test pemeringkatan seluruh nilai kelas eksperimen dan kelas kontrol data postes I dan II, lembar penugasan kecakapan proses sains kelas eksperimen dan kelas kontrol.

Ketiga, hasil pengujian $U$-Test pemeringkatan seluruh nilai kelas eksperimen serta kelas kontrol menggunakan analisis Mann Whitney ( $U$ - Test) yaitu, (1) rata-rata (mean) data postes I lembar penugasan kecakapan proses sains untuk kelas eksperimen 15,79 lebih besar daripada kelas kontrol 6,35 atau 15,79 > 6,35. (2) Rata-rata (mean) data postes II kecakapan proses sains kelas eksperimen 16,00 lebih besar daripada kelas kontrol 6,10 atau 16,00>6,10. Jadi, terdapat perbedaan pengaruh permainan problematika sains dengan pembelajaran metode pembelajaran konvensional untuk kecakapan proses sains pada anak usia 5-6 tahun.

Saran yang diajukan adalah bagi sekolah yaitu memberikan sebuah sarana dan fasilitas untuk kegiatan sains berupa percobaan sederhana. Pada kegiatan sains harus ada tahap pengamatan, mengklasifikasi, memberi kesimpulan, dan mengomunikasikan objek yang diamati. Implementasi kegiatan sains dilakukan untuk memperbaiki kualitas kecakapan proses sains anak. Bagi guru TK diharapkan dapat menstimulasi kecakapan proses sains anak dengan mengimplementasikan permainan problematika sains. Pada pelaksanaan permainan problematika sains, guru perlu memperhatikan beberapa hal seperti pemilihan materi yang tepat, aman, dan mengondisikan kelas dengan baik. Hal tersebut menjadi penting untuk terealisasikan kegiatan sains yang efektif dan memberikan pengalaman yang bermakna.

\section{DAFTAR RUJUKAN}

Bose, K., \& Seetso, G. (2016). Science and Mathematics Teaching Through Local Games in Preschools of Botswana. South African Journal of Childhood Education, 6(2), 9. https://doi.org/10.4102/sajce.v6i2.453

Dewi, A. C. (2012). Meningkatkan Kemampuan Sains Anak Usia Dini melalui Pembelajaran Berbasis Keterampilan Proses. Malih Peddas (Majalah Ilmiah Pendidikan Dasar), 1(2). https://doi.org/10.26877/malihpeddas.v1i2.301

Gallenstein, N. L. (2005). Engaging Young Children in Science and Mathematics. Journal of Elementary Science Education, 17(2), 27-41. https://doi.org/10.1007/bf03174679

Ibda, F. (2015). Perkembangan Kognitif: Teori Jean Piaget. Intelektualita, 3(1), 242904.

Morrison, K. (2012). Integrate Science and Arts Process Skills in the Early Childhood Curriculum. Dimensions of Early Childhood, 40(1), 31-38.

Moursund, D. (2006). Introduction to Using Games in Education: A Guide for Teachers and Parents. Book, 06, 1-155. https://doi.org/10.1038/s41598-018-27832-0

Mujianto, S. (2017). Analisis Daya Beda Soal. Taraf Kesukaran, Butir Tes, Validitas Butir Tes, Interpretasi Hasil Tes Valliditas Ramalan Dalam Evaluasi Pendidikan. Jurnal Manajemen dan Pendidikan Islam 2, 2(2), 192-213.

Oktaviani, M. A., \& Notobroto, H. B. (2014). Perbandingan Tingkat Konsistensi Norma dan Kependudukan, 3(2), $127-135$. Retrieved from http://journal.unair.ac.id/download-fullpapers-biometrikd8bc041810full.pdf

Osman, K. (2012). Primary science: Knowing About the World Through Science Process Skills. Asian Social Science, 8(16), 1-7. https://doi.org/10.5539/ass.v8n16p1

Petrovska, S., Sivevska, D., \& Cackov, O. (2013). Role of the Game in the Development of Preschool Child. Procedia - Social and Behavioral Sciences, 92(Lumen), 880-884. https://doi.org/10.1016/j.sbspro.2013.08.770

Risda Amini \& A. Munandar. (2010). Pengaruh model pembelajaran pendidikan lingkungan berbasis. Jurnal Penelitian Pendidikan, 11(1), 14-21.

Roza, M. M. (2012). Pelaksanaan Pembelajaran Sains Anak Taman Kanak-Kanak Aisyiyah Bustanul Athfal 29 Padang. Pesona PAUD, 1(1), 1-11.

Setia, K., Agustini, A., Gading, I., \& Tirtayani, L. A. (2016). Pengaruh Metode Pembelajaran Eksperimen terhadap Keterampilan Proses Sains pada Kelompok B Semester II. Journal Pendidikan Anak Usia Dini Universitas Pendidikan Ganesha, 4(2).

Sriwidadi, T. (2011). Penggunaan Uji Mann-Whitney pada Analisis Pengaruh Pelatihan Wiraniaga dalam Penjualan Produk Baru. Binus Business Review, 2(2), 751. https://doi.org/10.21512/bbr.v2i2.1221

Sudarmo, M. N. P., \& Mariyati, L. I. (2018). Kemampuan Problem Solving dengan Kesiapan Masuk Sekolah Dasar. Psikologia: Jurnal Psikologi, 2(1), 38. https://doi.org/10.21070/psikologia.v2i1.1267

Sumiyati. (2010). Kegiatan Sains dalam Kurikulum TK untuk Mengembangkan Kreativitas Anak Didik. Jurnal Pendidikan dan Kebudayaan, 16(3), 298. https://doi.org/10.24832/jpnk.v16i3.463

Susilowati, N. (2016). Pengenalan Sains Melalui Percobaan Sederhana pada Anak Kelompok B di KB-RA IT Al-Husna Yogyakarta. Jurnal Pendidikan Anak Usia Dini, 5(5), 551-560. 